\title{
(Un)doing Nationalism through Familial Metaphors: The Case of Modern China/Taiwan
}

Jennifer Meei-yau Wei*

\begin{abstract}
Ideals of femininities and masculinities (to a lesser extent) are often used to mobilise citizens in testing socio-political times. Familial roles such as mother and wife are prime targets for politicians crafting ideals of nationalism. Comparing the political rhetoric of two of the most prominent female politicians in Chinese/Taiwanese modern history, Mme. Chiang Kai Shek (Mme. CKS, 1989-2003) and Annette Lu (b. 1944), I argue that ideal familial roles have always intersected with politics during social transitions. Moreover, in the developing China/Taiwan contexts, these ideals parallel changes from feudalistic to modern society, and from authoritarian to democratic rule. By looking into the argumentative strategies and familial metaphors, I offer a comprehensive view on how gender, nation, and family values have been articulated in times of transition in Taiwan in the $20^{\text {th }}$ century.
\end{abstract}

Key words: gender, nationalism, family, familial metaphors

\footnotetext{
* Department of English Language and Literature, Soochow University, Taiwan; wei_jennifer@hotmail.com
} 


\section{Introduction}

Taiwan is situated at the strategic centre of the Pacific Ocean. It experienced a brief period of colonisation by the Dutch and the Spanish in the $16^{\text {th }}$ century and was one of their destinations before landing at Fujian, one of the provinces of China during the Qing dynasty, the last Chinese dynasty. At the beginning of the $20^{\text {th }}$ century, Taiwan became the first colony of Japan (1894-1945) as a result of the first Sino-Japanese War. It also experienced a 50-year period of authoritarianism as the then ruling Nationalist Kuomintang Party (KMT) retreated to the island after it lost the civil war to the Chinese communists in the late 1940s. In the 1980s, the island started to democratise rapidly with the opposition demanding changes and direct elections. In 1996, the island held the first presidential election in Chinese history; in 2000 the then oppositional Democratic Progressive Party (DPP) won the election and ended the 50-year monopoly of the KMT. Since the turn of the $21^{\text {st }}$ century, the island has experienced three party turnovers.

This paper uses modern China/Taiwan as a case study to demonstrate how ideals of femininity and masculinity and politics are mutually interconnected and how Chinese patriarchy and its impact on family values have been (re)positioned to meet national goals and personal ambitions in times of national crises at the turn of the $20^{\text {th }}$ century. It also explains how the same familial ideals have been repositioned for the political opposition platform as Taiwan was trying to shed layers of traditional identity to meet the demands of the democratised $21^{\text {st }}$ century.

These waves of socio-political transition, from Japanese colonialism (1894 to 1945) to KMT authoritarianism (1949 to 1987) to rapid democratisation since the 1980s, have made the island an interesting case to see how familial gender roles can be interpreted and reinterpreted during times of social change. To further illustrate the modern China/Taiwan case, I chose two of the most prominent female politicians in Chinese/Taiwanese politics, Mme. Chiang Kai-Shek (Mme. CKS, 1898 to 2003) and former Vice President Annette Lu (2000-2004, 2004-2008), to examine how ideals of family and gender roles/expectations are embedded in political transitions. Specifically, I am interested in how female politicians in China/Taiwan's modern period have framed familial gender roles such as wife, mother, and parent and have utilised ideas of family values for their personal and political convictions.

Following Brownell and Wasserstrom (2002) and Chang (2002, 2009), I see ideals of gender roles and politics as mutually intertwined, and I am interested in the following questions: 
1. How do political transitions from feudal society to modern state and from authoritarianism to democracy change the way we view gender roles and expectations?

2. If gender and politics are mutually interconnected, how do shifts in political ideology change the way politicians frame nationalism?

3. Does the Confucian emphasis on women's subordination and subservience still pervade $21^{\text {st }}$-century Taiwan?

I start with Mme. C.K.S., also known as Soong Mei-ling, the wife of the Generalissimo and President Chiang Kai-shek and sister-in-law to Dr. Sun Yat-sen, founder of the Republic of China (ROC). She played a very important role in rallying the Chinese people against Japanese invasion during the Second Sino-Japanese War (1937-1945) and went on a speaking tour in the U.S. in the 1940s to rally moral and monetary support. In addition, she saw women's subordinate status and illiteracy as one of the major culprits for China's malaise in modern times. She was active in advancing women's status and strongly emphasised women's education. Her conviction and vision were incorporated into Chinese nationalism and patriotism where women were shown to lead in all spheres of society, and their potential was unrestrained. Women were discursively constructed as strong and rebellious, and their defiance of Chinese patriarchy was conditionally granted so long as it was an act of patriotism. Gender socialisations were strategically targeted in cultivating xianqi liangmu, "able wives and wise mothers", where these familial roles could be incorporated into various national projects ${ }^{1}$ ( $\mathrm{cf}$. Diamond 1975). The well-defined, well-bounded complementary gender roles and the adaptations of Chinese traditions into patriotism parallel China/Taiwan's transition from a feudal society to a modern nation state and coincide with Taiwan's authoritarianism from the 1940 s to the 1980 s.

Annette $\mathrm{Lu}$ was a rising political star in the 1970s and her belief in seeing gender equality as a fundamental human right served as one of the driving forces for her political beliefs. By embedding her gender convictions into her democratic appeals, her rhetoric constantly attacked Chinese patriarchy and Japanese militarism for women's inferior status to men and framed the status of Taiwan as a result of failed colonialism. Her adaptations of wife, mother, and parent seen from women/Taiwan's 'victim status' challenged the cardinal belief in women's dependence on and obedience to men as dictating gender relations. Lu's stress on agency and independence in both gender and

1 This refers to the New Life Movement launched by Chiang Kai-shek in 1934. With the endorsement of the national government, the movement spread and became part of the official ideology. According to Diamond (1975), the aim of the movement was a "social regeneration of China" through a revival of the moral principles by way of neo-Confucian moral teaching $(8)$. 
politics resonated with the many national/international issues prevailing on the island from the 1970s to the 90s.

The (un)doing of nationalism incorporate both political rhetoric promoting visions of family, nation, and international politics with national programmes such as education and war-aids in testing times. The discursive strategies and nationalised programmes not only helped them establish their career but have also influenced the lives of generations of women and men in modern China/Taiwan. I will start with the unpacking of the socio-political contexts to explicate how nationalistic ideologies help promote certain talents in familial roles and why they are needed in developing China/Taiwan from the 1940 s to 1970 s.

\section{2 xianqi liangmu, "able wives and wise mothers"}

I adopt a critical approach to deconstruct the political contexts to question how and why certain ideas of femininities are emphasised for nationalistic purposes. Unpacking how ideological effects of nationalism and patriotism give rise to specific features of femininities can help explicate how and why gender related "virtues" are stressed and normalised. When Mme. C.K.S. tried to consolidate global female talents and virtues to build a stronger modern China in the midst of the West's and Japan's military expansions, gendered and familial metaphors such as wife, mother, and parent were iconised with heightened nationalism and patriotism. The rhetorical and related national programmes aimed to rally international support and to re-regulate gender relations under Confucian dictates with which individual rights and freedom were erased and penalised under the construction and popularisation of xianqi liangmu, "able wives and wise mothers". George Lakoff's analysis of metaphors as a cognitive shorthand helps us understand abstract and complicated ideas by comparing the two seemingly different notions and by transferring the compatible features of the simple to the difficult one (Lakoff and Johnson 1980). While the transfer of experiences from one domain to another can be benign in most daily communication, it can be used by skilful politicians to call for action. That is, metaphorical mapping from easy to difficult and from concrete to abstract is not only cognitive but also political during periods of regime transition and moral in calling for international support and for naturalising nationalism and patriotism. 
Xianqi liangm $u^{2}$ was popularised during the period of modernisation in China/Taiwan, and the modern rendition of "able wives and wise mothers" was charged with nationalism and militarism. Gendered and nationalised talents and virtues were carefully selected, enforced, and naturalised to ensure the survival of a Chinese nation in times of adversity. This is not uniquely Chinese, since the ideas and phrases were borrowed from Japanese as Japan was the first nation in Asia to modernise successfully (Nakamura 2014). Among the many talents and virtues needed for national projects, duty, loyalty, and sacrifice were stressed. Discursively, historical precedence and metaphors were used to inculcate their importance. A good case in point is from "Women's work" (Soong 1941, 306-338) where Mme. CKS not only outlined the importance of women's contributions to war time projects but also highlighted the most needed services and virtues as she said:

The fact that Chinese women are rising to unusual heights of self-sacrifice is, however, nothing new. Here is a story from the Warring States Period in Chinese history (fifth to third century B.C.) which shows that the capacity to forget the self in the face of greater issues is inherent and is as true today as it was in the past.

The Chi kingdom sent an army to attack the Lu Kingdom. On the $\mathrm{Lu}$ border a general of the Chi forces, at a distance, observed a woman carrying one child and leading another. As the Chi army pressed closer, the woman put down the child she was carrying, picked up the one she was leading, and resumed her journey. The abandoned child began to cry, but the woman paid no attention to it.

The General approached the crying child and asked: "Who is that woman?" "My mother."

Hurriedly the astonished General approached the woman and asked why she acted as she did.

"The child in my arms is my brother's. The one whom I have deserted is my own. The Chi army is advancing pace, and as I have not the strength to care for two, I was obliged to abandon my son.”

"Which is dearer to you-your son, or your brother's son?" he inquired.

\footnotetext{
2 According to Diamond (1975), the "social regeneration of China" as stressed by Chiang Kai-shek serving as Commander in Chief in the nationalist government in the 1930s incorporated moral principles of $l i$, $y i$, lian, and $c h i$ (propriety, justice, honesty, and self-respect), a neo-Confucian revival which would return to the traditional moral teachings and apply them to ordinary matters (8).
} 
"Of course, my own son. But to save my own child is selfishness; to rescue my brother's is duty. Although my son suffers, it is but right." [italics mine]

The Chi General thereupon withdrew his army from the Lu border.

Returning to his lord, he reported: "Lu is unconquerable. Even a woman of the common people places duty before self. How much more should one expect of its scholars and officials? Hence I withdrew my army.”

"How great is the strength of a sense of duty. Although only a woman, yet upon her depended the destiny of the country," the recorder of the Annals commented.

And today China is as unconquerable as was the Kingdom of $\mathrm{Lu}$ in the past. (Soong 1941, 337-338)

In addition to citing historical precedence, metaphor is another way to transfer the needed familial values to nation building. Metaphorically, by comparing the new nation to a family, the leaders of the country are the parents of the family and the loyalty to one's family members is now transferred to the leaders of the country and to their demand for service. These ideas/ideals of family and familial roles were different from the traditional ideas when women's education, status, and contributions to society were marginalised and in sharp contrast to a family-oriented feudal society where clan loyalty prevailed over public service, such as sacrificing one's life as well as one's offspring for the greater good. 
Figure 1 summarises how metaphor can help transferring Chinese clannishness to the newfound nation state:

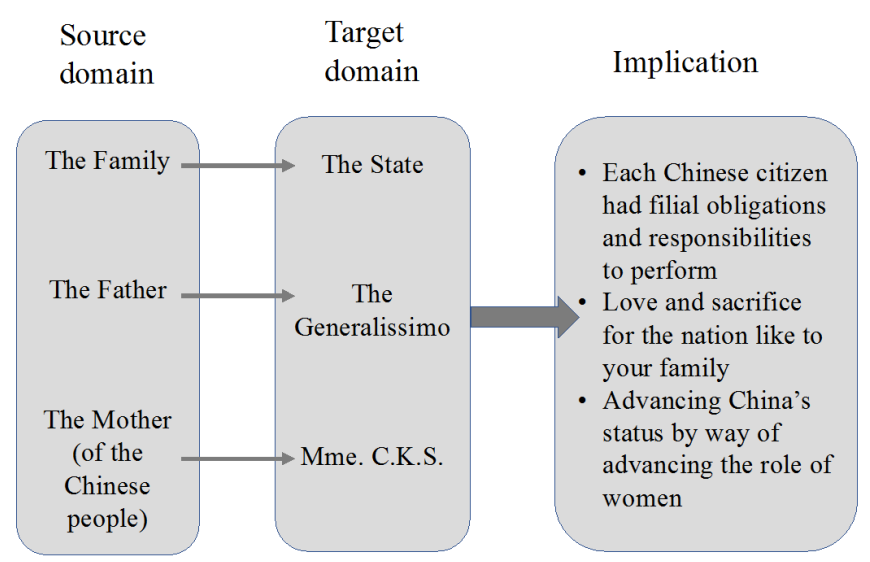

Figure 1: Mme. CKS’s familial metaphor

In the following paragraphs, I will use excerpts from Mme. C.K.S.'s speeches to demonstrate how the ideals of parents and women were appropriated to stress the importance of obligation and self-sacrifice.

(1)

The ancient mothers conceived it to be their obligation to bring up their children so that they might devote their lives to the welfare of the nation [italics mine]. That principle and that practice are needed now more than ever, for we have a ruthless invader stalking our land who must be exterminated, just as all his evil influences must be eradicated. (Soong 1941, 58-59)

(2)

There are women in our past for us to honor and to emulate; there are some to avoid but to study as a warning. There were women of literary brilliance such as Pan Chao of the Han dynasty, author of the Nu Chieh, or the Precepts for Women. There were, too, heroic figures such as Hua Mu-lan, Lian Hung-yu, and Chin Liang-yu. These women were of those who dedicated their brains and their energies to the upbuilding and improvement of the nation [italics mine]. On the reverse side were what are regarded as selfseeking women such as Tan Tsi, Pao Chia, Wu Tsei-tien, and Yang Kueifei. Perhaps they were guilty of harmful intrigue, or perhaps they wielded a baneful influence which reduced the rulers of those times to degenerates. 
Perhaps they did both and nothing good for the country. (Soong 1941, $55-56)$

In Excerpts (1) and (2), Mme. C.K.S. lays out the obligations for mothers in times of national crises and uses opposing examples from Chinese history to point out good and bad women - those who dedicated their brain and energy to nation building and those who were self-seeking, respectively. In order to avoid the guilt of harmful intrigue or wielding baneful influence, women's talents and energy should be directed at service to the country.

The next excerpt stresses the importance of education for women and how investing in women's potential talents can advance China's venture to the modern world. This is also a way to inform her audience of the 'wisdom' of mothers (and fathers) on the importance of women's education.

$(3)^{3}$

My parents seemingly broke every Chinese tradition in sending me as a child America-ward to study instead of accumulating money for an ample dowry. This was considered not only the summum bonum for all young Chinese girls but the wisest course and the duty of affectionate parents. By sending their daughters America-ward to school, however, they were but fulfilling their vision of what educated women could contribute toward a strong revitalized modern China. (Soong 1942)

By using her own example and her parents' seeming defiance of Chinese traditional expectations of women, Mme. C.K.S. advances China's status (from traditional to modern) by way of advancing the role of women (from monetary to intellectual investment). These goals are consistent with overall Chinese modernisation where educating women as important national investment and incorporating women's production/reproduction into national projects were needed.

\footnotetext{
3 Mme. CKS spoke at the inauguration for the Mayling Soong Foundation for Eastern culture at Wellesley College in June 1942.
} 
The next example shows how gendered international relations are used to reflect the imbalance of power relations between China and the West during war time:

\section{$(4)^{4}$}

Since China was opened to the world, relations between East and West may be divided into three stages.

In the first the weapon of the West toward China was always force.

By pointing a gun at her the West made her suffer humiliation after humiliation.

All her port cities were opened, in an actual as well as a metaphorical sense, at the point of the bayonet.

Then began the second stage.... When Japan forced war upon us [italics mine] in 1937-which interfered with China's foreign trade-the West became very sympathetic. China was immediately applauded, perhaps, at first, rather condescendingly.

But the interest, although sympathetic, was detached as that of spectators at a college football game, cheering from the safety of the stand while taking no personal risk in the game themselves.... We were regarded by him with a kind of puzzled interest inspired by good-will but still uncomprehending. (Soong 1942)

China under international military threats is seen by Mme. C.K.S. as a woman forced to open herself up and who suffered humiliation after humiliation (see the italics for emphasis). The West and Japan are comparatively forceful and condescending, and their detached attitude is compared to that of college football spectators. The iconic imageries such as "open up" and "football" are both sexual and gendered. They are used to remind her international audience of the atrocity and the indifference from the West that China endured.

Mme. C.K.S.'s rhetoric thus uses historical precedence and familial metaphors to reappropriate ideals of family and familial roles during wartime. The gendered metaphor with a feminised China and a masculinised West is intended to rally the necessary aid and attention needed for China under attack. These political rhetorics and deeds are all synchronised for a nationalised and modernised China by advancing women's status and incorporating their talents into various national projects aimed at survival and

4 The April 19, 1942 edition of the New York Times Magazine with the title "First Lady of the East Speaks to the West." 
modernisation. These discursive practices helped iconise xianqi liangmu, "able wives and wise mothers", in modern China, naturalised nationalism and patriotism, and at the same time they marginalised individual rights and freedoms.

\section{The Social Gender under jia, "familial lineage", in Chinese Contexts}

I turn my attention to how ideas of gender have been problematised in Chinese contexts and draw out their relevance to my study in seeing gender intersect with social and political issues. Brownell and Wasserstrom (2002) suggest that we put gender centre stage in order to understand transitions of modernity in different contexts. Ideas of gender in Chinese contexts do differ from those in the West; for example, before intense contact with the West, Chinese gender concepts were anchored in beliefs about family structure and social roles more so than beliefs about biological sex. Men and women were plural categories rather than unified categories opposed to each other; motherhood and womanhood were not directly linked to heterosexuality, and reproducing the lineage was a more important aspect of sexuality (ibid, 34). The emphasis of family structure in constructing gender roles remains distinctive even after China's transition from feudalism into modernity and the pragmatic imperative of protecting as well as producing the familial lineage remains strong. Changes involved in sexuality began gaining importance in the 1990s, and femininities and masculinities were constructed less in roles such as daughter/son but remained prominent in the roles of mother/father and wife/husband.

Barlow (1991) argues that in imperial China there was no generic category of woman: there were $n u$, "daughters", in the family, $f u$, "wives", and $m u$, "mothers". Two neologisms - ordinarily translated as funu or nuxing "woman"-were created when sexidentity politics first emerged in the May Fourth Movement (1919). Nuxing was a Western inspired concept used by Republican-era reformers to name the newly discovered transcendent category of woman (ibid, 8). Barlow's study on theorising women in the Chinese context further provides specific examples for how gender is seen and enacted through the dictate of familial structure (or protocol), as she explains that

what appear as "gender" are yin/yang differentiated positions: not two anatomical sexes, but a profusion of relational, bound, unequal dyads, each signifying differences and positioning differences analogically. A $n u$ "daughter" unequally related to parents and parents-in-law. A xiaozi a "filial son" is differentially unequal to mother and father, yin to their yang. A 
$f u$ is a "wife", tied in a secondary relation to her husband. A xianfu is a "wife", who grasping the powers visited upon the secondary yin term masters through familiarity with protocol. (ibid, 136)

Barlow further explains that jia, "familial lineage", should be conceptualised as protocol as it is neither a mere code, nor a map, nor a 'role.' It rests on a shifting foundation, the cosmic activity of yin/yang, yet provides advice and counsel on achieving naturalised, normative, and gendered relational subjects. Protocols instruct. They provide continuity and reinforce subject positions by linking the archaic past in which these protocols were first established to contemporary texts (ibid, 137).

Rosenlee (2006) explains that in Chinese society, the category of "woman" describes the role of a wife and mother, and the role of a wife and mother is, in turn, perceived as constitutive of women's gender identity. It is only through occupying the kinship roles that a woman becomes socially recognisable. Marriage is the definitive marker of womanhood, and hence by definition an unmarried girl is, in a sense, not fully gendered (ibid, 126). Her book on Confucianism and women further explains that in the case of Chinese women, the concept of woman signifies a set of kinship roles, a ritually proper sphere and division of labour within the hierarchical kinship system. In other words, genderisation coincides with ritualisation and civilisation in Chinese society, where a gendered being is also a being that embodies ritual propriety and hence civility (ibid, 151). The importance of Confucian ethics in seeing the family structure/relation as mirror to that of the nation and society cannot be underestimated when we try to understand gender relations, socialisation, and hierarchy in Chinese contexts. Again, Rosenlee (2006) provides the following account:

Confucian ethics assumes the priority of the family, and familial virtue as the necessary condition for the actualization of public virtue. An unfilial son/daughter is also an untrustworthy subject and one way to ensure the harmony and longevity of the state is to groom trustworthy subjects by grooming filial sons/daughters. Once the foundation is firm, the embodiment of public good would be firm as well. Or, to put it in contemporary political rhetoric, strong family values mitigate social discord. (ibid, 156)

Diamond (1975) suggests adopting a feminist perspective - a heightened awareness of problems shared by women across cultural boundaries and class lines - at different stages of economic development and under differing political systems when studying positions of women in modern Taiwan (ibid, 4-5). She further suggests that women's positions under the KMT were similar to those in Nazi Germany, and she explains the parallels as "both were strongly militaristic and strongly anti-communist regimes, infused with 
a neo-puritanism and distrust of human impulses unhampered by the strictest control" (ibid, 13).

I have reviewed work on gender in the Chinese context before and after contact with the West to see how gender specifics resonate with deeper social and political issues. One feature stands out in Chinese gender symbolism: sex-linked symbols are often secondary to other more fundamental principles of moral and social structure in which gender is situated within broader networks of social relations that take precedence over the dyadic sexual relation (Brownell and Wasserstrom 2002, 26). The importance of familial roles in Chinese contexts has their historical roots and has been proven pervasive even with and during periods of political transition. These points should serve as important pretexts to understand how and why familial roles along with other discursive practices are vital for our understanding of gender, nation, and family values in Chinese political discourses.

\section{Lu's Political Rhetoric on Family and Familial Roles}

Madame C.K.S.'s ideals for gender roles and expectations can be best summarised in "able wives and wise mothers", an epithet popularised in wartime China in the 1930s and during much of Taiwan's KMT rule from the late 1940s to the 1980s. Decades later, as the island engaged in more drastic democratisation in the late 1970s, Annette $\mathrm{Lu}$ (1944-) became one of the most prominent female politicians both for her convictions about human rights and her advocacy of feminism. Mme. C.K.S. and Ms. Annette Lu might seem worlds apart in their upbringing and in what they advocated for but in Chinese/Taiwan modern history they perhaps rank as the two most influential female politicians given what they have accomplished. For my interest in how changing political contexts influence family values and gender roles/expectations, I am interested in comparing how $\mathrm{Lu}$ framed her beliefs and missions and linked them to filial responsibilities or rights of individuals as wives, mothers, and daughters. Doris Chang (2009) sees Annette Lu and Mme. C.K.S. both as social feminists as they try to extend familial roles of mothers and wives beyond the domestic realm into the public arena in order to serve the nation. Though both were forward thinking in their times and incorporated women's issues into their own personal convictions and political ambitions, their ideals of parents, mothers, and wives were drastically different. Moreover, although Lu was born and raised in a different place and time when Taiwan was in transition from authoritarianism to a civil society, she nevertheless never abandoned Confucian family values and never embraced radical feminism as some of her supporters would have ex- 
pected. Lu was more conscious of the gender inequality which she had experienced and stressed human rights (and especially women's rights) issues since the 1970s when the island was under martial law (Lu and Esarey 2014).

Lu was the first female vice president elected by popular vote in Chinese history and was also the only vice president in Taiwan who served two terms (2000-2008). Her upbringing and background further differentiate her from many of the fe/male politicians in Asia. Born to an ordinary family, twice in her childhood she was nearly put up for adoption. Rather than through family influence, her rise in politics began with her participation in street protests against the KMT's monopoly of power. In 1971, she initiated a Taiwan feminism movement, and in 1979, she was arrested and imprisoned for six years on charges of sedition. In the speech given at the rally shortly before her arrest, Lu saw the uncertain status of Taiwan as the result of failed colonialism and used that as reason for seeking independence.

Figure 2 summarises Lu's stance as a feminist politician, seeing herself as a victim of gender inequality in Taiwan, women as victims of Chinese patriarchy and Japanese chauvinism, as well as Taiwan as victim of "failed parental guidance" - by the Qing dynasty, the U.S., and Japan - resulting in Taiwan's undecided national status:

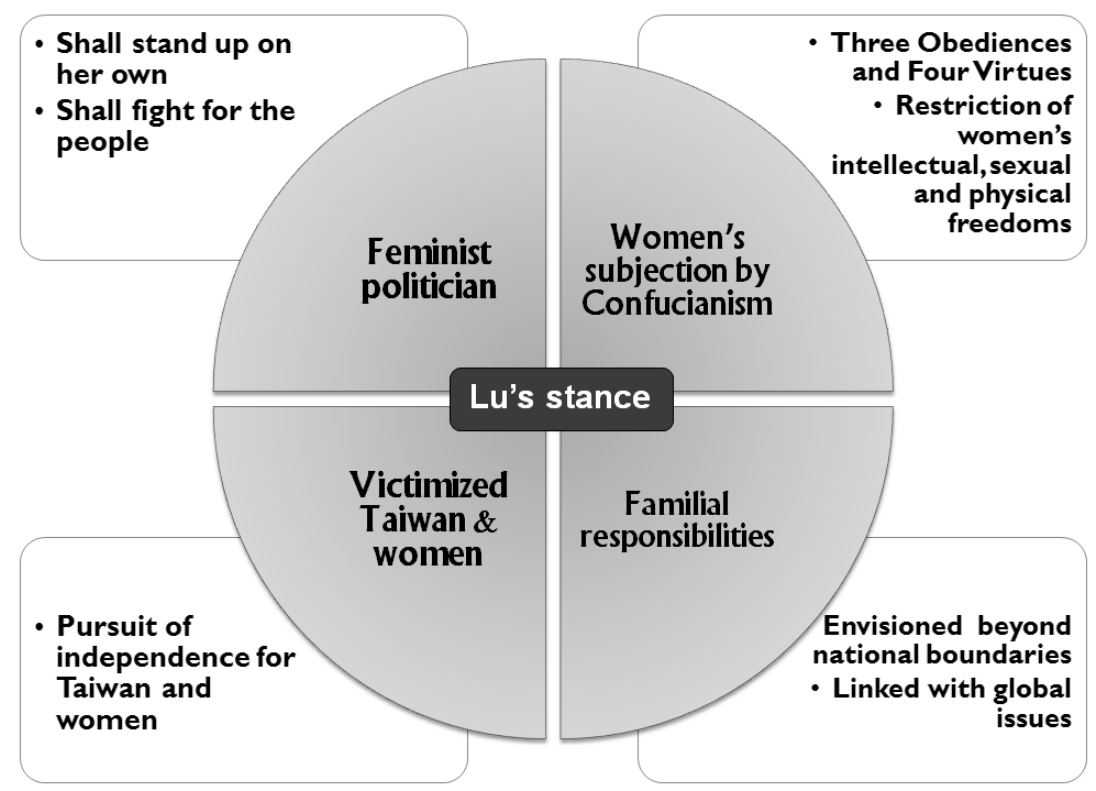

Figure 2: Annette Lu's stance 
In the next section, I quote parts of Lu's speeches to further explicate these points.

The first is an interview with Renate Schmidt (SPD) in Bonn, Germany, ${ }^{5}$ where she summarises how and why she combined gender inequality with human rights issues and used it as part of her political platform for independence.

(5)

Q: Were you jailed for your involvement in the women's movement?

A: No, but you can put it that way, perhaps. This is mainly because I have moved from contemplating the fate of women's issues to the fate of the Taiwanese people. I found that there are similarities between the two: both constitute more than half of the population in Taiwan, and both are not minorities. Nevertheless, both have suffered long overdue discrimination and marginalization. This reflects a common problem - women and Taiwanese need more awakening and make more efforts to achieve human rights. Six years into my fight with the women's movement, having experienced all kinds of smears and setbacks, I decided to get involved with political movements to awaken the Taiwanese people. ( $\mathrm{Lu} 1987)$

The next excerpt shows how she appropriates the familial role of parent in Taiwan's post-colonial contexts and uses them to argue for independence.

(6)

Before Japan's surrender, the U.S., the U.K., and the R.O.C. agreed on a declaration to return Taiwan to China when Japan gave in. However, as the Korean War broke out after the surrender of Japan, the U.S. government, realizing that it couldn't withdraw its forces in Asia, issued the Truman Doctrine, claiming that while Japan was asked to give up sovereignty over Taiwan, the treaty did not identify the country to which Taiwan was returned.

Accordingly, the legal status of Taiwan was yet to be determined. In other words, we Taiwanese were abandoned and given to Japan by our birth parents (Qing, the last dynasty in Chinese history); Japan thus became our foster parents. Then when the Japanese lost the war and their power, they abandoned us again. However, this doesn't mean that our birth parents are qualified or able to adopt us back.

5 The interview was published by Awakening Magazine (Funu xinzbi Zazhi) (Lu 1987, 16-17). 
Ladies and gentlemen, our country will be facing a serious crisis in three weeks, because the U.S., who has been supporting us for 30 years, has given us up. Of course, we were wrong for having been relying too much on America in the past 30 years. After all, the U.S. is itself an imperialist. ... It has been 35 years since Taiwan was separated from Japanese rule. Isn't it the time for us to become an independent country? Shouldn't we stand up and strive for the independence of this country now? ( $\mathrm{Lu} \mathrm{1987)}$

In this excerpt, Taiwan is given up and adopted by various colonial powers, which are referred to by Lu as 'birth parents' and 'foster parents', and its uncertain status is the result of failed colonialism. By victimising Taiwan and pointing to the indecision of international powers, Lu urges for the independence of the country:

(7)

Everybody, (as for) our grandfathers and grandmothers, nobody asked for their consensus, and they were changed from Chinese to Japanese. They can be changed into someone else in the future. This is very much against human rights. ( $\mathrm{Lu} \mathrm{1987)}$

In the last part of the speech, Lu adopts a more indirect strategy, albeit with the same persuasive force as the speech was given at a time when Taiwan was under martial law and authoritarianism dictated the words and actions of citizens. With the linguistic strategy of no-naming - not pointing out the reference of her intention, she engages her audience in the imagination of what had been happening to Taiwan's national identities (Flowerdew and Leong 2010). The lack of consensus among the people to decide what they were is seen by $\mathrm{Lu}$ as a violation of human rights for which she is a firm advocate.

By victimising Taiwan, her repositioning of parents - both natural/birth and foster - with their failed responsibilities in internationally troubled times results in Taiwan's undecided national status. She uses that as part of her political platform to seek independence both for Taiwan and for women. Her personal experience again is relevant for her convictions, as she points out, even today, that except for her, all Asian female national leaders have come from prestigious political families where either their father or husband or brother was originally the powerful political figure. Some of them in fact are political widows, 'widow politics' being a unique phenomenon in Asia. But as Lu sees it, a feminist politician shall stand up on her own, not on her family ties; shall fight for the people, not for her family or herself ( $\mathrm{Lu} 2013)$.

In the next excerpt, Lu attacks Chinese Confucianism's view of women's subordination to men and uses it as one of her personal and political platforms to liberate herself, women, and Taiwan on their path to independence: 
Chinese Confucianism subjected women to the so-called Three Obediences and Four Virtues. The Three Obediences were to obey her father before marriage, obey her husband during marriage, and obey her sons in widowhood. The Four Virtues were fidelity, physical charm, propriety in speech, and skill at needlework. Together, these traditions actually created Three Bondages for women: Bound heads, Bound waists, and Bound feet to restrict women's intellectual, sexual, and physical freedoms.

Under Japanese chauvinism, women were taught nothing but to serve and to please men, women always bent their waists, bowed their heads, and surrendered to men. If Simone de Beauvoir thought that European women were the Second Sex, what would she have made of women in Asia? (Lu 2008)

Here, we see that Chinese traditions are challenged, and the previously exhorted truism for gendered relations - women's submission and subordination to men - is targeted as the culprit for women's persistently inferior status. Lu further puts this relation in an international context and questions the status of Asian women. Her anti-traditional views won her both admirers and enemies. In fact, her stress on being independent and on not seeing China/Taiwan as a family either by way of Mme. C.K.S.'s ideology or that of the Chinese Communist Party's (CCP) made her controversial, and this subjected her to the international limelight (see the quoted Excerpt (9). Yet she chose neither to compromise nor sacrifice her convictions, and she gave speeches on how media attention, especially inflammatory attention, affected her.

The following excerpt from the speech made for BPW International in Mexico sums up her dilemma and her conviction.

It certainly was a culture shock for Taiwan society. The people had only seen the first lady standing next to the president, so some people joked that I should behave like the president's "political wife.” So, whenever I said something political or sensitive, the media and general public felt uncomfortable and tried to silence me, to render me powerless. The situation made the first two years of my vice presidency incredibly miserable. Even the People's Republic of China aimed its attacks at me, as an unconventional woman, calling me the "scum of the nation" and "insane." China's men still maintained the traditional attitude that a woman playing politics was like a "hen crowing at dawn," that is, to play a wrong role. (Lu 2008) 
Here we see that $\mathrm{Lu}$ tries to defy the conventional view of a wife as passive and supportive of her husband (the president in this example). Her defiance of the traditional expectations of familial roles did not win her much support in the media and invited more criticism from China where criticisms were directed at her false expectations of women as leaders. That is, she not only refuses to be a conventional 'political wife', her views on family also go beyond the nationalistic view that had dominated Taiwan for much of the $20^{\text {th }}$ century. Worse, she urges people in Taiwan and beyond to take up issues resonating beyond the national borders.

In the next excerpt, Lu stresses women's caring and nurturing qualities, which would most benefit beyond the familial confines and should extend to international affairs:

We women are the best housekeepers for the house, and also for the earth. It is time for us women, as the nurturers of life and as half of the population on earth, to launch a green renovation for green civilization! The concept of green civilization stresses the following four interests of balance: 1 . The value of life, 2. The standard of livelihood, 3. The quality of environment, and 4 . The benefit of industrial investment. ( $\mathrm{Lu} \mathrm{2011)}$

In this speech, as in many speeches that she has given in recent years, Lu stresses feminine qualities such as caring and nurturing, but unlike Mme. C.K.S.'s vision of family and nation, Lu's ideals extend to global and related issues, such as green renovation and green civilisation. In this sense, her use of familial metaphors such as 'housekeeper' helps her extend her ideals from domestic/national issues to international/global ones.

Born half a century apart and in times where China/Taiwan was experiencing intense nationalism, modernisation, and ultimately democratisation, Mme. C.K.S. and Annette Lu both chose to incorporate gender issues into their political rhetoric to promote their political agendas and to advance their personal convictions. While Mme. C.K.S. used Chinese traditions, especially those concerning Confucian doctrines on women's subordination and submission to men and incorporating them to a nation in order to promote militaristic and nationalistic projects, Lu used some of the same traditions to launch feminism and seek independence for both women and Taiwan in the 1970s. While Mme. C.K.S. emphasises women's sacrifices and contributions to national projects, Lu stresses women's rights and personal advancements. The former built her political career by being one of the most successful political wives in the modern Chinese period while the latter entered politics to counter injustice, to defend human rights, and refused to be a 'political wife' when she served as Vice-president (20002008). Moreover, Lu's family values extend to global issues such as the protection of 
environmental and human rights. Both of their ideals for family, parents, as well as for wives and mothers, are still binary. Mme. C.K.S. adapts Chinese nationalism and patriotism to dictate gender roles and normalise gender socialisations. Annette Lu frames her belief on gender equality and women's independence with human rights and as the driving force for her long fight for independence for herself, women, and Taiwan. Both women embed gender/familial discourse with elements of culture and politics when modern China/Taiwan was going through socio-political transitions at the turn of the $20^{\text {th }}$ century, reinventing modern China/Taiwan from feudalism to modernity and from authoritarianism to an emerging democracy.

Contrasting Lu's gender discourse to that of Mme. C.K.S. helps answer the questions raised at the beginning, i.e., whether political ideology affects a candidate's view of family values and influences how nationalism is framed. The results are positive for both Mme. C.K.S.'s appropriation of elements of Chinese nationalistic and patriarchal perspectives and Annette Lu's seeing both women and Taiwan as independent and viable and extending her idea of a family beyond domestic and national boundaries and family values to global issues.

\section{Conclusions and Suggestions}

In this paper, I have compared the political rhetoric of female politicians in Chinese/Taiwanese politics to test how and if their ideas and ideals for women and family values are different and whether they can be used for national objectives and to express personal convictions. By elucidating the socio-political contexts and by contrasting Mme. C.K.S. and Annette Lu at the height of Taiwan's modernisation period, during its one-party authoritarian period, and well into the $21^{\text {st }}$ century, I have shown how Chinese/Taiwanese ideals for women have always been linked tightly to their obligations to the family, reflecting some of the most powerful political ideology in Chinese/Taiwanese politics.

I started with xianqi liangmu, an epithet popularised in Mme. C.K.S.'s rhetoric, and explained that by likening family to nation and the obligations of familial roles to those of citizens, she helped modern China/Taiwan to infuse citizens with patriotism and to harness the virtues of wives and mothers to war time projects, education, and industrialisation. In contrast, for Annette $\mathrm{Lu}$, who was born half a century later and who suffered gender discrimination and political repression, her personal and political convictions helped frame wives and mothers from a liberal feminist perspective, which put femininity above masculinity and extended the obligations to care for family and nation to serving the world. In addition, Lu's political ideology in seeing the island as inde- 
pendent from China marked her family model/values as different from that of Mme. C.K.S. Changing times and ideologies might have set Mme. C.K.S. and Annette Lu worlds apart but they both adopted binary gender norms and appropriated elements of Chinese patriarchy and nationalism to advance their political agenda.

Figure 3 summarises how female roles are (re)interpreted during political transitions in the speeches of Mme. CKS and Annette Lu:

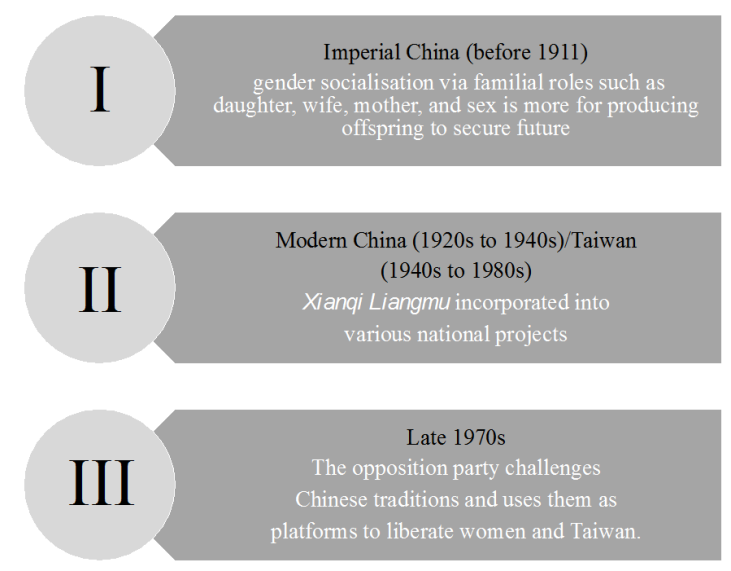

Figure 3: Changing gender roles in modern China/Taiwan

A few more words on whether family values and Confucian doctrines for wives and mothers will remain potent metaphorical breeding grounds for $21^{\text {st }}$-century Taiwan serve as a salient conclusion. As one of the prominent female politicians in Taiwan, Annette Lu broke away from the pattern of typical Asian political wives, mothers, and daughters, where family ties and political ideologies pave the road to power and domination in politics. Lu has adopted different family models focusing on human rights and environmental issues. Breaking away from traditional familial roles as the pretext for gender socialisations and adaptations of family values might now help frame femininity and masculinity in more pragmatic ways. Future studies could compare Mme. C.K.S's and Lu's political rhetoric to other emerging democracies in East Asian countries, where authoritative regimes aided by cultural or religious ideologies have produced systematic sexism in politics. With the changing socio-political forces, especially rising economic powers and opposition parties, different family values and changing familial roles might be emerging. 


\section{Acknowledgement}

The paper is supported by MOST 012-2410-H-031-034 and MOST 106-2410-H-031048. A previous draft was presented at the AARC 2018 conference where the audience, especially Nikola and Christine provided insightful suggestions. I also want to thank Professor Su Hsi-yao at NTNU for commenting, Michael Tanangkingsing for editing and Dong-yi Lin for formatting.

\section{References}

Barlow, Tani. 1991. "Theorizing Woman: Funu, Guojia, Jiating [Chinese Women, Chinese State, Chinese Family].” Genders 10: 132-160.

Brownell, Susan, and Jeffrey Wasserstrom. 2002. Chinese Femininities, Chinese Masculinities: A Reader. Berkeley: University of California Press.

Chang, Doris. 2002. “Daughters of Formosa: Feminist Discourses and Women's Movements in Taiwan, 1920-2002.” PhD diss., Ohio State University.

Chang, Doris. 2009. “Two Women, Two Visions of Nationhood for Taiwan: Madame Chiang Kai-shek and Hsiu-lien Annette Lu.” Asian Journal of Women Studies 15 (2): 7-32.

Diamond, Norma. 1975. "Women under Kuomintang Rule: Variations on the Feminine Mystique." Modern China 1 (1): 3-45.

Flowerdew, John, and Solomon Leong. 2010. "Presumed Knowledge in the Discursive Construction of Socio-Political and Cultural Identity.” Journal of Pragmatics 42: 2240-2252.

Lakoff, George, and Mark Johnson. 1980. Metaphors We Live by. Chicago: University of Chicago Press.

Lu, Annette. 1987. “Interview with Annette Lu.” Interview by Renate Schmidt. Awakening Magazine, November 1987, 16-17.

Lu, Annette. 2008. "Write 'Her Stories' into History-Are We Ready?” Keynote speech at the $26^{\text {th }}$ Congress of the BPW International, Mexico City, October 25, 2008.

Lu, Annette. 2011. "When Women Lead: Green Renovation Will Save the Earth.” Speech at IFBPW 27th International Congress, Helsinki, Finland. June 20, 2011.

Lu, Annette. 2013. “Peace Initiative for Marine Disputes.” Opening address for Global Women's Peace Network, Manila, Philippines, January 11, 2013.

Lu, Hsiu-lien, and Ashley Esarey. 2014. My Fight for a New Taiwan: One Woman's Journey from Prison to Power. Washington: University of Washington Press.

Nakamura, Momoko. 2014. Gender, Language and Ideology: A Genealogy of Japanese Women's Language. Philadelphia: John Benjamins Publishing Company.

Rosenlee, Li-Hsiang Lisa. 2006. Confucianism and Women: A Philosophical Interpretation. New York: State University of New York Press.

Soong, Mei-ling. 1941. China Shall Rise Again. New York: Harper and Brothers Publishers.

Soong, Mei Ling. 1942. "First Lady of the East Speaks to the West." New York Times, April 19, 1942. 